\title{
Lactobacillus hammesii sp. nov., isolated from French sourdough
}

Correspondence
Maher Korakli
maher.korakli@wzw.tum.de

\author{
Rosica Valcheva, ${ }^{1}$ Maher Korakli, ${ }^{2}$ Bernard Onno, ${ }^{1}$ Hervé Prévost, ${ }^{1}$ \\ Iskra Ivanova, ${ }^{3}$ Matthias A. Ehrmann, ${ }^{2}$ Xavier Dousset, ${ }^{1}$ Michael G. Gänzle ${ }^{2}$ \\ and Rudi F. Vogel ${ }^{2}$
}
${ }^{1}$ Laboratoire de Microbiologie Alimentaire et Industrielle (LMAI), Unité de Recherche OM2A, ENITIAA, rue de la Géraudière, BP 82225, 44322 Nantes Cedex 3, France
${ }^{2}$ Lehrstuhl für Technische Mikrobiologie, Technische Universität München, Weihenstephaner Steig 16, 85350 Freising, Germany
${ }^{3}$ Faculty of Biology, University of Sofia, Department of Microbiology, 8bul Dragan Tzankov, 1423 Sofia, Bulgaria

\begin{abstract}
Twenty morphologically different strains were chosen from French wheat sourdough isolates. Cells were Gram-positive, non-spore-forming, non-motile rods. The isolates were identified using amplified-fragment length polymorphism, randomly amplified polymorphic DNA and 16S rRNA gene sequence analysis. All isolates were members of the genus Lactobacillus. They were identified as representing Lactobacillus plantarum, Lactobacillus paralimentarius, Lactobacillus sanfranciscensis, Lactobacillus spicheri and Lactobacillus sakei. However, two isolates (LP38 ${ }^{\top}$ and LP39) could be clearly discriminated from recognized Lactobacillus species on the basis of genotyping methods. 16S rRNA gene sequence similarity and DNA-DNA relatedness data indicate that the two strains belong to a novel Lactobacillus species, for which the name Lactobacillus hammesii is proposed. The type strain is $\mathrm{LP} 8^{\top}\left(=\mathrm{DSM} 16381^{\top}=\mathrm{CIP} 108387^{\top}=\mathrm{TMW}^{1.1236^{\top}}\right)$.
\end{abstract}

Lactic acid bacteria (LAB), especially the genera Lactococcus, Lactobacillus and Leuconostoc, are the most important group of micro-organisms involved in food fermentation (Hammes \& Tichaczek, 1994; Herrero et al., 1996). The microbial ecology of sourdough fermentation is determined by various exogenous and endogenous parameters (Vogel et al., 1999). The sourdough microflora comprises $\mathrm{LAB}$ and yeasts existing in symbiotic relationships (Hammes \& Gänzle, 1998). Yeasts contribute predominantly to dough leavening, whereas LAB are responsible for acidification, aroma formation and sensorial as well as nutritional improvement of the fermented product (Böcker et al., 1990; Hammes et al., 1996).

France, as with many other countries, has a long tradition in bread making. Reports concerning the LAB biodiversity observed in natural French sourdough revealed a broad spectrum of different $\mathrm{LAB}$, predominant among which are

Published online ahead of print on 22 October 2004 as DOI 10.1099/ ijs.0.63311-0.

Abbreviations: AFLP, amplified-fragment length polymorphism; LAB, lactic acid bacteria; RAPD, randomly amplified polymorphic DNA.

The GenBank/EMBL/DDBJ accession number for the 16S rRNA gene sequence of Lactobacillus hammesii LP38 $^{\top}$ is AJ632219.

RAPD-PCR and AFLP patterns of the sourdough isolates and selected lactobacilli are available as supplementary figures in IJSEM Online. members of the genus Lactobacillus, e.g. Lactobacillus plantarum, Lactobacillus brevis and Lactobacillus sanfranciscensis (Bervas, 1991; Infantes, 1992; Onno \& Roussel, 1994; Gabriel et al., 1999). For the development of stable starter cultures, a thorough analysis of the typical sourdough microflora is indispensable. In this study, the biodiversity of $\mathrm{LAB}$ in three fermented wheat sourdoughs from different regions of France was investigated. A preliminary screening based on the observed phenotypic characteristics led to the isolation of 20 bacterial strains. In order to obtain more information concerning their taxonomic status at the species and strain level, amplified-fragment length polymorphism (AFLP), randomly amplified polymorphic DNA (RAPD) and 16S rRNA gene sequence analyses were performed. These analyses allowed the identification of almost all LAB involved in these sourdough fermentations. However, based on phenotypic and genotypic results, two Lactobacillus strains were not assignable to any recognized species. Consequently, we describe and classify these strains as representing a novel Lactobacillus species, for which we propose the name Lactobacillus hammesii sp. nov.

The bacterial diversity of three French wheat sourdoughs was investigated at the LMAI - ENITIAA (Nantes, France). These were firm sourdoughs maintained by back slopping or rafraîchi in different specific conditions for each sourdough in terms of ratio (sourdough/dough), temperature 
$\left(18-26^{\circ} \mathrm{C}\right)$ and back slopping frequency. Twenty colonies were isolated on modified MRS agar (De Man et al., 1960) supplemented with $1 \%(\mathrm{w} / \mathrm{v})$ maltose and $0.5 \%(\mathrm{w} / \mathrm{v})$ fresh yeast extract prepared according to the method of Kline \& Sugihara (1971). LAB were grown anaerobically at $30^{\circ} \mathrm{C}$ for $48 \mathrm{~h}$. The distribution of various colony forms was recorded and distribution percentages of the various isolates were determined. Pure culture was obtained by successive subculturing on identical medium. For biochemical characterizations mMRS4 medium was used (Stolz et al., 1996). Lactobacillus reference strains were obtained from the DSMZ or from the TMW culture collection at Lehrstuhl für Technische Mikrobiologie (Freising, Germany).

DNA was isolated according to the method of Marmur (1961) with the modifications described by Ehrmann et al. (2003). The isolated DNA was used for AFLP, RAPD and $16 \mathrm{~S}$ rRNA gene sequence amplification. RAPD-PCR was carried out as described by Ehrmann et al. (2003) and AFLP analysis was performed according to Schmidt et al. (2003). Data analysis was performed using the BIONUMERICS software (Applied Maths). This program recorded the normalized electrophoretic patterns of the densitometric traces, grouped the isolates by the Pearson productmoment correlation coefficient and performed UPGMA (unweighted pair group method with arithmetic averages) cluster analysis of the bands. The complete $16 \mathrm{~S}$ rRNA gene was amplified using primers $616 \mathrm{~V}$ and $630 \mathrm{R}$ according to Ehrmann et al. (2003). A phylogenetic tree was constructed by the neighbour-joining method using BIONUMERICS software. The cell wall composition was determined at DSMZ according to Schleifer \& Kandler (1972). DNA-DNA relatedness analyses were carried out as described by De Ley et al. (1970), with the modifications described by Huß et al. (1983) and Escara \& Hutton (1980), and the $\mathrm{G}+\mathrm{C}$ content of the DNA was determined according to Mesbah et al. (1989). All experiments were carried out in duplicate by DSMZ staff.
Gram staining, cell morphology and catalase activity were examined after $24 \mathrm{~h}$ of incubation on MRS agar. Sugar fermentation patterns were determined using the API $50 \mathrm{CH}$ kit (bioMérieux) over a period of $72 \mathrm{~h}$. D/L-Lactate production was measured using an enzymic kit from Microzym (Diffchamb). To determine the temperature and $\mathrm{pH}$ growth optima as well as salt tolerance, cultures were grown on mMRS4 medium, harvested, washed with fresh medium, inoculated (1\%) and incubated at various temperatures $\left(15,20,25,30,35,40\right.$ and $\left.45^{\circ} \mathrm{C}\right)$ and $\mathrm{pH}$ values $(3$, $4,4 \cdot 5,5,5 \cdot 5,6,7$ and 8$)$. Bacterial growth was monitored by measurement of the optical density at $590 \mathrm{~nm}$. Production of ammonia from arginine was determined according to the method of Abo-Elnaga \& Kandler (1965). Mannitol formation from fructose was demonstrated by HPLC as described by Müller et al. (2001). All tests for biochemical characterizations were carried out at least in duplicate.

The LAB microfloras of three wheat sourdoughs prepared by back slopping propagation from previous batches were characterized. The total LAB count in the studied sourdoughs ranged from $1 \cdot 6 \times 10^{9}$ to $2 \cdot 1 \times 10^{9}$ c.f.u. $\mathrm{g}^{-1}$ and the final sourdough $\mathrm{pH}$ was between $4 \cdot 0$ and $4 \cdot 2$. Twenty morphologically different colonies were isolated from each sourdough and these were phenotypically characterized. All cells were Gram-positive, catalase-negative, facultatively anaerobic rods. The isolates were identified using AFLP, RAPD and 16S rRNA gene sequence analysis. All were members of the genus Lactobacillus. They were identified as Lactobacillus plantarum, Lactobacillus paralimentarius, Lactobacillus sanfranciscensis, Lactobacillus spicheri and Lactobacillus sakei. However, two isolates, $\mathrm{LP}^{\mathrm{T}}{ }^{\mathrm{T}}$ and LP39, were clearly discriminated from recognized Lactobacillus species. The complete sequences (1559 bp) of the 16S rRNA genes of these two strains were determined. The two sequences showed high similarity $(99.7 \%)$, suggesting that the strains belong to the same species. In a neighbour-joining dendrogram (Fig. 1) based

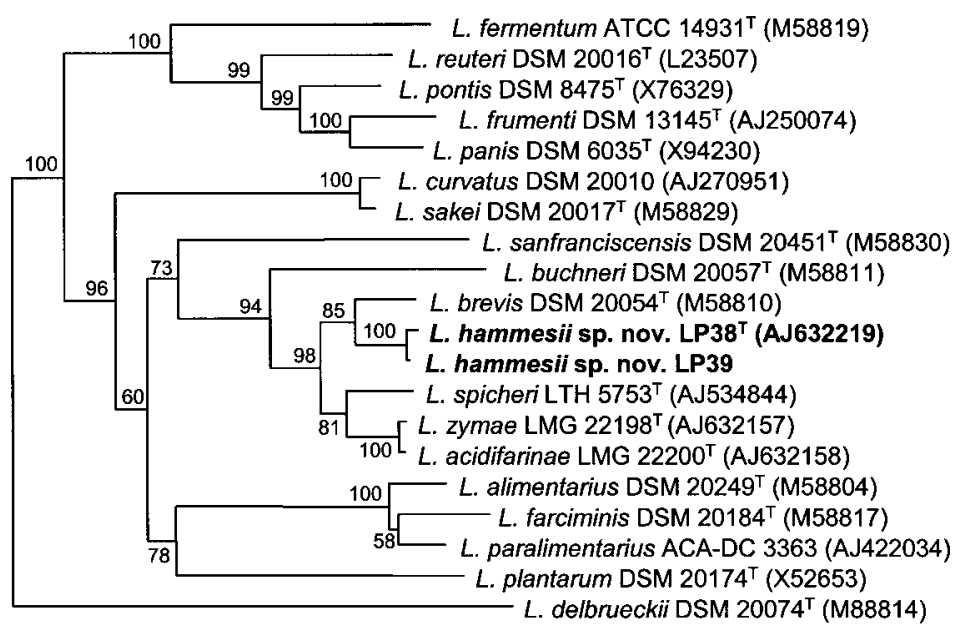

0.01
Fig. 1. Phylogenetic tree derived from $16 \mathrm{~S}$ rRNA gene sequence analysis showing the position of Lactobacillus hammesii sp. nov. strains LP38 $^{\top}$ and LP39 among selected lactobacilli. The tree was generated by the neighbour-joining method and Lactobacillus delbrueckii was used as the outgroup. Bootstrap values based on 1000 replications are given at nodes. Bar, 0.01 substitutions per nucleotide position. 
on 16S rRNA gene sequences obtained from this study and from the GenBank database, strains $\mathrm{LP} 38^{\mathrm{T}}$ and LP39 clearly belong to the genus Lactobacillus, and are positioned close to Lactobacillus brevis, Lactobacillus spicheri, Lactobacillus zymae and Lactobacillus acidifarinae, all of which have been isolated from sourdoughs (Vancanneyt et al., 2005).

DNA-DNA reassociation analyses were performed including the three most closely related strains based on $16 \mathrm{~S}$ rRNA gene sequence analysis. DNA-DNA relatedness values of $\mathrm{LP}^{\mathrm{T}} 8^{\mathrm{T}}$ to Lactobacillus spicheri, Lactobacillus zymae and Lactobacillus brevis were $64 \cdot 7 \pm 2 \cdot 5,43 \cdot 3 \pm 4 \cdot 3$ and $18 \cdot 3 \pm 8 \cdot 1 \%$, respectively. These values are below the threshold of $70 \%$ suggested for species delineation (Stackebrandt \& Goebel, 1994), indicating that strain $\mathrm{LP} 38^{\mathrm{T}}$ represents a separate genomic species. The DNA $\mathrm{G}+\mathrm{C}$ content of $\mathrm{LP} 38^{\mathrm{T}}$ is $52.6 \mathrm{~mol} \%$, which is within the range (32-55 mol\%) reported for Lactobacillus (Kandler \& Weiss, 1986). Analysis of the cell wall composition of strain $\mathrm{LP} 38^{\mathrm{T}}$ revealed the presence of lysine and aspartic acid, indicating an A $4 \alpha$ L-Lys-D-Asp peptidoglycan type. Strain LP $38^{\mathrm{T}}$ accounted for about $30 \%\left(5 \times 10^{8}\right.$ to $6 \times 10^{8}$ c.f.u. $)$ of the total $\mathrm{LAB}$ in investigated sourdoughs, and the rest were strains of the species Lactobacillus plantarum, Lactobacillus sanfranciscensis, Lactobacillus paralimentarius, Lactobacillus spicheri and Lactobacillus sakei. Physiological properties and sugar fermentation patterns of strains LP38 ${ }^{\mathrm{T}}$ and LP39 are shown in Table 1.
Müller et al. (2001) reported the application of RAPD-PCR for the analysis of the microflora of an industrial sourdough. When the RAPD patterns of the 20 isolates were compared to those of reference lactobacilli usually found in sourdough, strain $\mathrm{LP}^{\mathrm{T}} 8^{\mathrm{T}}$ showed no similarity to any other isolates or reference Lactobacillus strains (see Supplementary Fig. A in IJSEM Online), which confirmed the $16 \mathrm{~S}$ rRNA gene sequence analysis results. Torriani et al. (2001) reported discrimination between the closely related species Lactobacillus plantarum, Lactobacillus paraplantarum and Lactobacillus pentosus using RAPD-PCR and AFLP. Analogously to RAPD analysis, AFLP patterns of the sourdough isolates were compared with those of reference Lactobacillus strains. AFLP grouped the 20 sourdough isolates into five groups identical to those obtained by RAPD (Supplementary Fig. B).

The microflora of the investigated sourdoughs showed the typical composition frequently reported in French and Italian sourdoughs, Lactobacillus plantarum, Lactobacillus sanfranciscensis, Lactobacillus paralimentarius and Lactobacillus sakei (Bervas, 1991; Infantes, 1992; Onno \& Roussel, 1994; Hammes et al., 1996; Gobetti et al., 1994). However, isolation and identification of nine isolates as Lactobacillus spicheri, which has been isolated as a novel species from rice sourdough (Meroth et al., 2004), represents the first isolation of this species from a wheat sourdough. Strain $\mathrm{LP}^{\mathrm{T}}{ }^{\mathrm{T}}$ exhibited no similarity to any other sourdough isolates or Lactobacillus reference strains using RAPD or

Table 1. Differential phenotypic characteristics of Lactobacillus hammesii sp. nov. strains LP38 and LP39 and closely related Lactobacillus species

+, Positive; -, negative; W, weakly positive; ND, not determined. All strains produce a mixture of D- and L-lactate. Data for reference strains were taken from Hammes \& Vogel (1995) (L. brevis) and Meroth et al. (2004) (L. spicheri).

\begin{tabular}{|c|c|c|c|c|}
\hline \multirow[t]{2}{*}{ Characteristic } & \multicolumn{2}{|c|}{ L. hammesii sp. nov. } & \multirow{2}{*}{$\begin{array}{c}\text { L. brevis } \\
\text { DSM } 20054^{\mathrm{T}}\end{array}$} & \multirow{2}{*}{$\begin{array}{c}\text { L. spicheri } \\
\text { DSM } 15429\end{array}$} \\
\hline & LP38 $^{\mathrm{T}}$ & LP39 & & \\
\hline $\mathrm{G}+\mathrm{C}$ content $(\mathrm{mol} \%)$ & $52 \cdot 6$ & ND & 46 & 55 \\
\hline Peptidoglycan type & L-Lys-D-Asp & ND & L-Lys-D-Asp & L-Lys-D-Asp \\
\hline $\mathrm{NH}_{3}$ from arginine & - & - & + & + \\
\hline Growth at $15 / 45^{\circ} \mathrm{C}$ & $+1-$ & ND & $+1-$ & $+1-$ \\
\hline \multicolumn{5}{|l|}{ Acid production from: } \\
\hline L-Arabinose & + & + & + & - \\
\hline D-Xylose & + & + & - & + \\
\hline Methyl $\beta$-xyloside & + & + & - & + \\
\hline Galactose & + & W & $\mathrm{W}$ & - \\
\hline Mannose & + & - & - & - \\
\hline Mannitol & $\mathrm{W}$ & + & $\mathrm{W}$ & - \\
\hline$N$-Acetylglucosamine & + & + & - & - \\
\hline Aesculin & + & $\mathrm{W}$ & + & - \\
\hline Cellobiose & + & - & - & - \\
\hline Melibiose & - & - & + & - \\
\hline Trehalose & + & - & - & - \\
\hline Raffinose & - & - & + & - \\
\hline
\end{tabular}


AFLP, and analysis of the complete $16 \mathrm{~S}$ rRNA gene sequence revealed that the bacterium is closely related to Lactobacillus brevis and Lactobacillus spicheri. On the basis of these results we propose that strains $\mathrm{LP} 38^{\mathrm{T}}$ and LP39 be classified in the genus Lactobacillus as Lactobacillus hammesii sp. nov.

\section{Description of Lactobacillus hammesii sp. nov.}

Lactobacillus hammesii (ham.me.si'i. N.L. gen. n. hammesii of Hammes, in honour of Walter P. Hammes, a German scientist who contributed to the microbiological and technological development of wheat and rye sourdough research).

Cells are Gram-positive, catalase-negative, non-motile, nonspore-forming straight rods that occur singly $(0.5 \times 2-$ $4 \mu \mathrm{m}$ ), in pairs or occasionally in short chains. Colonies on MRS agar appear white and circular with a smooth surface and edges (1-1.5 mm in diameter after 2 days of growth). Cells grow well in liquid or solid MRS under aerobic conditions. Strain $\mathrm{LP} 38^{\mathrm{T}}$ grows at $15^{\circ} \mathrm{C}$ but not at $45^{\circ} \mathrm{C}$. Optimum temperature for growth is $30-35^{\circ} \mathrm{C}$ and the optimal initial $\mathrm{pH}$ is $4 \cdot 7-7 \cdot 2$. Specific growth rate of strain LP38 $8^{\mathrm{T}}$ in mMRS4 at $\mathrm{pH} 6.2$ and at $30^{\circ} \mathrm{C}$ is $0.42 \pm 0.01 \mathrm{~h}^{-1}$. Strain $\mathrm{LP} 38^{\mathrm{T}}$ is able to grow well at up to $2 \% \mathrm{NaCl}$; at $6.6 \% \mathrm{NaCl}$ the specific growth rate is $26 \%$ (100\% without $\mathrm{NaCl}$ ). Glucose is metabolized heterofermentatively. Glucose, maltose, arabinose, xylose, galactose, mannose, cellobiose and trehalose are fermented by strain $\mathrm{LP}^{2} 8^{\mathrm{T}}$. Ammonia is not produced from arginine. Fructose is used either as an energy source or as an electron acceptor and is reduced to mannitol. Both strains $\mathrm{LP}_{3} 8^{\mathrm{T}}$ and LP39 produce lactate at a ratio of $45 \%$ L-lactate to $55 \%$ D-lactate. Strain $\mathrm{LP} 38^{\mathrm{T}}$ grows significantly better in media containing electron acceptors such as fructose in addition to a carbon source (maltose or glucose). HPLC analysis revealed that strain $\mathrm{LP} 38^{\mathrm{T}}$ produces lactic acid and ethanol from glucose or maltose and, in the presence of fructose, produces lactic and acetic acid. Peptidoglycan structure is A4 $\alpha$ L-Lys-D-Asp type and the DNA G $+\mathrm{C}$ content is $52 \cdot 6 \mathrm{~mol} \%$.

The type strain is $\mathrm{LP}^{2} 8^{\mathrm{T}}\left(=\mathrm{DSM} 16381^{\mathrm{T}}=\mathrm{CIP} 108387^{\mathrm{T}}=\right.$ TMW $1.1236^{\mathrm{T}}$ ).

\section{Acknowledgements}

We are grateful to Florian Waldherr for biochemical characterization, Isabelle Hue for technical support and Carrie Hew for revision of the manuscript. Luc De Vuyst, Vrije Universiteit Brussel, is acknowledged for providing 16S rRNA gene sequences of Lactobacillus zymae and Lactobacillus acidifarinae ahead of publication. This work was partially supported by the French Ministry (Ministère des Affaires Etrangères) and by the Federation of European Microbiological Societies (FEMS).

\section{References}

Abo-Elnaga, I. G. \& Kandler, O. (1965). Zur Taxonomie der Gattung Lactobacillus Beijerinck. I. Das Subgenus Streptobacterium OrlaJensen. Zentbl Bakteriol Parasitenkd Infektionskr Hyg 119, 1-36 (in German).
Bervas, E. (1991). Mise au point de levains bactériens pour la panification. Thèse de Doctorat, Université Blaise Pascal, ClermontFerrand, France (in French).

Böcker, G., Vogel, R. F. \& Hammes, W. P. (1990). Lactobacillus sanfrancisco als stabiles element in einem Reinzucht-SauerteigPräparat. Getreide Mehl Brot 44, 269-274 (in German).

De Ley, J., Cattoir, H. \& Reynaerts, A. (1970). The quantitative measurement of DNA hybridization from renaturation rates. Eur J Biochem 12, 133-142.

De Man, J. C., Rogosa, M. \& Sharpe, M. E. (1960). A medium for the cultivation of lactobacilli. J Appl Bacteriol 23, 130-135.

Ehrmann, M. A., Müller, M. R. A. \& Vogel, R. F. (2003). Molecular analysis of sourdough reveals Lactobacillus mindensis sp. nov. Int J Syst Evol Microbiol 53, 7-13.

Escara, J. F. \& Hutton, J. R. (1980). Thermal stability and renaturation of DNA in dimethyl sulfoxide solutions: acceleration of the renaturation rate. Biopolymers 19, 1315-1327.

Gabriel, V., Lefebvre, D., Vayssier, Y. \& Faucher, C. (1999). Characterisation of microflora from natural sourdoughs. Microbiol Alim Nutr 17, 171-179.

Gobetti, M., Corsetti, A. \& Rossi, J. (1994). The sourdough microflora: interactions between lactic acid bacteria and yeasts. Appl Microbiol Biotechnol 41, 456-460.

Hammes, W. P. \& Gänzle, M. G. (1998). Sourdough breads and related products. In Microbiology of Fermented Foods, pp. 199-216. Edited by B. J. Wood. London: Chapman \& Hall.

Hammes, W. P. \& Tichaczek, P. S. (1994). The potential of lactic acid bacteria for the production of safe and wholesome food. $Z$ Lebensm Unters Forsch 198, 193-201.

Hammes, W. P. \& Vogel, R. F. (1995). The genus Lactobacillus. In The Lactic Acid Bacteria, the Genera of Lactic Acid Bacteria, vol. 2, pp. 19-54. Edited by B. J. B. Wood \& W. H. Holzapfel. London: Blackie Academic \& Professional.

Hammes, W. P., Stolz, P. \& Gänzle, M. (1996). Metabolism of lactobacilli in traditional sourdoughs. Adv Food Sci 18, 176-184.

Herrero, M., Mayo, B., Gonzalez, B. \& Suarez, J. E. (1996). Evaluation of technologically important traits in lactic acid bacteria isolated from spontaneous fermentations. J Appl Bacteriol 81, 565-570.

Huß, V. A. R., Festl, H. \& Schleifer, K. H. (1983). Studies on the spectrophotometric determination of DNA hybridisation from renaturation rates. Syst Appl Microbiol 4, 184-192.

Infantes, M. (1992). Etude des levains naturels de panification provenant de différentes régions françaises. Thèse de Doctorat, Institut National Agronomique Paris - Grignon, France (in French).

Kandler, O. \& Weiss, N. (1986). Genus Lactobacillus Beijerinck 1901, $212^{\mathrm{AL}}$. In Bergey's Manual of Systematic Bacteriology, vol. 2, pp. 1209-1234. Edited by P. H. A. Sneath, N. S. Mair, M. E. Sharpe \& J. G. Holt. Baltimore: Williams \& Wilkins.

Kline, L. \& Sugihara, T. F. (1971). Microorganisms of the San Francisco sour dough bread process. II. Isolation and characterization of undescribed bacterial species responsible for the souring activity. Appl Microbiol 21, 459-465.

Marmur, J. (1961). A procedure for the isolation of deoxyribonucleic acid for micro-organisms. J Mol Biol 3, 208-218.

Meroth, C. B., Hammes, W. P. \& Hertel, C. (2004). Characterisation of the microbiota of rice sourdoughs and description of Lactobacillus spicheri sp. nov. Syst Appl Microbiol 27, 151-159.

Mesbah, M., Premachandran, U. \& Whitman, W. B. (1989). Precise measurement of the $\mathrm{G}+\mathrm{C}$ content of deoxyribonucleic acid by highperformance liquid chromatography. Int J Syst Bacteriol 39, 159-167. 
Müller, M. R. A., Wolfrum, G., Stolz, P., Ehrmann, M. A. \& Vogel, R. F. (2001). Monitoring the growth of Lactobacillus species during a rye flour fermentation. Food Microbiol 18, 217-227.

Onno, B. \& Roussel, P. (1994). Technologie et microbiologie de la panification au levain. In Bactéries Lactiques, vol. II, pp. 293-321. Edited by H. de Roissart \& F. M. Luquet. Grenoble: Lorica (in French).

Schleifer, K. H. \& Kandler, O. (1972). Peptidoglycan types of bacterial cell walls and their taxonomic implications. Bacteriol Rev 36, 407-477.

Schmidt, H., Ehrmann, M. A., Vogel, R. F., Taniwaki, M. H. \& Niessen, L. (2003). Molecular typing of Aspergillus ochraceus and construction of species specific SCAR-primers based on AFLP. Syst Appl Microbiol 26, 138-146.

Stackebrandt, E. \& Goebel, B. M. (1994). Taxonomic note: a place for DNA-DNA reassociation and 16S rRNA sequence analysis in the present species definition in bacteriology. Int J Syst Bacteriol 44, 846-849.

Stolz, P., Hammes, W. P. \& Vogel, R. F. (1996). Maltosephosphorylase and hexokinase activity in lactobacilli from traditionally prepared sourdoughs. Adv Food Sci 18, 1-6.

Torriani, S., Clementi, F., Vancanneyt, M., Hoste, B., Dellaglio, F. \& Kersters, K. (2001). Differentiation of Lactobacillus plantarum, L. pentosus and L. paraplantarum species by RAPD-PCR and AFLP. Syst Appl Microbiol 24, 554-560.

Vancanneyt, M., Neysens, P., De Wachter, M. \& 8 other authors (2005). Lactobacillus acidifarinae sp. nov. and Lactobacillus zymae sp. nov., from wheat sourdoughs. Int J Syst Evol Microbiol 55, 615-620.

Vogel, R. F., Knorr, R., Müller, M. R. A., Steudel, U., Gänzle, M. G. \& Ehrmann, M. A. (1999). Non-dairy lactic fermentations: the cereal world. Antonie van Leeuwenhoek 76, 403-411. 